\title{
DIET DIVERTIKULITIS
}

\author{
Dewa Ayu Ari Dwiyanti ${ }^{1}$, Putu Adi Suputra² \\ ${ }^{1}$ Prodi Kedokteran, Universitas Pendidikan Ganesha \\ ${ }^{2}$ Prodi Kedokteran, Universitas Pendidikan Ganesha \\ e-mail: ayu.ari.dwiyanti@undiksha.ac.id, adi.suputra@undiksha.ac.id
}

\begin{abstract}
Abstrak
Divertikulitis adalah peradangan pada divertikula ( kantong kecil yang menonjol yang dapat terbentuk di lapisan sistem pencernaan,terutama di usus besar) dan merupakan komplikasi penting dari penyakit divertikular. Patofisiologi dari divertikulitis adalah penyumbatan kantung divertikulum oleh fecalith, yang dengan iritasi pada mukosa menyebabkan peradangan tingkat rendah, kemacetan dan obstruksi lebih lanjut. Divertikulitis dapat dibedakan menjadi dua yaitu divertikulitis tidak rumit dan divertikultis rumit. Diverikulitis ini memiliki gejala seperti mual, muntah , nyeri abdomen, konstipasi, Kelemahan dan keletihan. Pengobatan divertikulitis dilakukan sesuai dengan tergantung pada seberapa parah kondisi yang dialami. Jika divertikulitis yang dialami berat atau rumit maka diperlukan penanganan reseksi bedah, sedangkan divertikulitis ringan atau tidak rumit dimana belum mengalami komplikasi dapat diberikan pengobatan antibiotik ataupun modifikasi diet. Modifikasi diet contohnya diet tinggi serat untuk mengoptimalkan pergerakan usus mereka, namun ini disarankan setelah episode akut telah diselesaikan dan diet FODMAP (Fermentable, Oligo, Disakarida, Monosakarida, serta Poliol) yang rendah dapat membantu mencegah terulangnya divertikulitis. Diet tinggi serat adalah modifikasi dari susunan makanan biasa dengan menambah bahan pangan yang banyak mengandung serat pangan, sedangkan FODMAP (Fermentable, Oligosakarida, Disakarida, Monosakarida, serta Poliol), adalah kelompok heterogen dari karbohidrat dan poliol rantai pendek yang sangat mudah difermentasi tetapi kurang terserap.
\end{abstract}

Kata kunci: Divertikulitis, Diet Tinggi Serat, dan Diet Rendah FODMAP

\begin{abstract}
Diverticulitis is inflammation of the diverticula (small raised pouches that can form in the lining of the digestive system, especially in the large intestine) and is an important complication of diverticular disease. The pathophysiology of diverticulitis is blockage of the diverticulum sac by fecaliths, which with irritation of the mucosa causes low-grade inflammation, congestion and further obstruction. Diverticulitis can be divided into two, namely uncomplicated diverticulitis and complicated diverticulitis. This divericulitis has symptoms such as nausea, vomiting, abdominal pain, constipation, weakness and fatigue. Diverticulitis treatment is carried out according to how severe the condition is. If the diverticulitis is severe or complicated, surgical resection is required, while mild or uncomplicated diverticulitis that has not yet experienced complications can be given antibiotic treatment or diet modification. Diet modifications such as a high-fiber diet to optimize their bowel movements, however, are recommended after the acute episode has been resolved and a low FODMAP diet (Fermentable, Oligo, Disaccharides, Monosaccharides, and Polyols) can help prevent recurrence of diverticulitis. A high-fiber diet is a modification of the usual food composition by adding food ingredients that contain lots of dietary fiber, while FODMAP (Fermentable, Oligosaccharides, Disaccharides, Monosaccharides, and Polyols), are a heterogeneous group of carbohydrates and short-chain polyols which are very easy to ferment but less absorbed.
\end{abstract}

Keywords : Diverticulitis, High Fiber Diets, and Low FODMAP Diets 


\section{PENDAHULUAN}

Penyakit divertikular (divertikulosis, divertikulitis) adalah istilah umum untuk keberadaan divertikula, kantung kecil di dinding usus besar (kolon). Penyakit diverticular ini dahulu sangat jarang terjadi namun, sekarang penyakit diverticular ini sangat umum dan sering terjadi bahkan penyakit diverticular ini merupakan salah satu gangguan gastrointestinal yang paling umum terjadi di antara pasien rawat inap dan rawat jalan. (Strate, 2019)

Patogenesis dari penyakit divertikular bersifat multifaktorial dan diduga berhubungan dengan inflamasi ringan, perubahan mikrobiota kolon, dan disfungsi sistem imun, saraf enterik, dan disfungsi sistem otot. ( Deery, 2017 ) Pada umumnya penyakit divertikular ini ditemukan pada negara maju, dimana terjadi sedikit lebih sering di AS daripada di Eropa, dan merupakan kondisi yang jarang terjadi di Afrika. Namun, beberapa indikasi tersedia bahwa prevalensi divertikulosis kolon meningkat di seluruh dunia, mungkin karena perubahan gaya hidup. (Tursi , 2013) Pada negara-negara maju penyakit divertikular sangat sering dijumpai bahkan seiring bertambahnya usia juga akan meningkatakan resiko terjadinya penyakit divertikular.Jika divertikular mengalami peradangan maka akan terjadi divertikulitis. Divertikulitis adalah manifestasi klinis paling umum dari divertikulosis.

\section{DIVERTICULOSIS and DIVERTICULITIS}

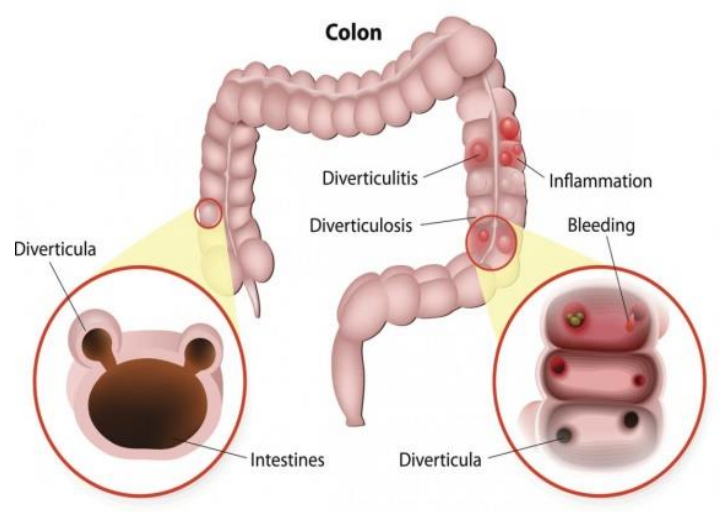

Gambar 1. Diverticulosis and Diverticulitis

Divertikulitis adalah peradangan pada divertikula ( kantong kecil yang menonjol yang dapat terbentuk di lapisan sistem pencernaan, terutama di usus besar). dan merupakan komplikasi penting dari penyakit divertikular. Divertikulitis memiliki jumlah sel mast yang lebih tinggi di semua lapisan dinding kolon, dan juga memiliki infiltrat limfositik dan neutrofilik yang signifikan, tergantung pada tingkat keparahan penyakit. ( Deery, 2017 ) Divertikulitis dapat ditangani jika pengobatan yang diberikan benar namun terkadang divertikulitis ini mengalami kekambuhan dimana Sekitar sepertiga hingga seperempat pasien yang sembuh dari satu episode divertikulitis akan mengalami kekambuhan. (Carter, 2017)

Divertikulitis dapat dibedakan menjadi dua yaitu divertikulitis tidak rumit dan divertikultis rumit. Divertikulitis tidak rumit adalah tanpa komplikasi yang melibatkan penebalan dinding kolon dan perubahan inflamasi peri-kolon. Sedangkan, divertikulitis rumit ditandai dengan adanya abses, peritonitis, obstruksi, dan / atau fistula.( Swanson, 2018)

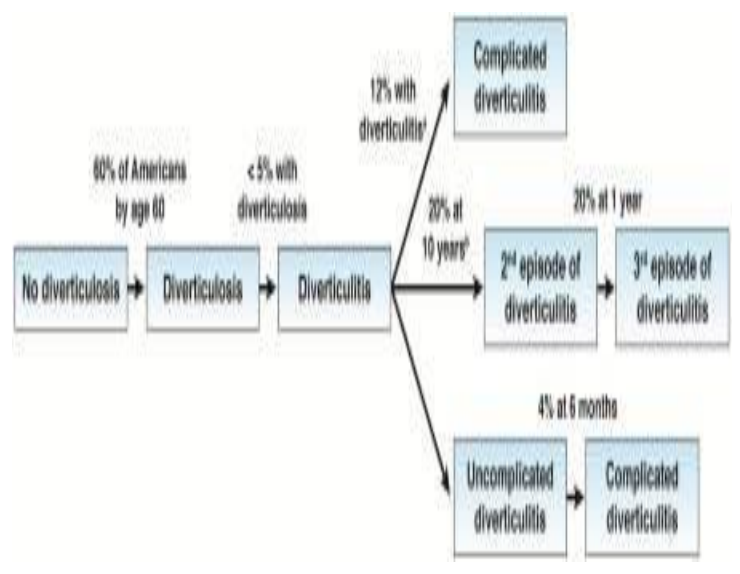

Gambar 2. Natural history of diverticulosis and diverticulitis

Divertikulitis adalah infeksi bakteri lokal, yang mungkin akibat perforasi lokal di daerah divertikulum. Lokasi dari penyakit, derajat iritasi peritoneum, dan penyebaran infeksi dapat menentukan tingkat keparahan divertikulitis, lokalisasi, dan luasnya nyeri perut. Namun, terkadang perforasi luas terjadi dengan peritonitis difus dan pembentukan abses (Siegenthaler, 2007) 
Gejala dari divertikulis tergantung dari beratnya infeksi dan ada tidaknya komplikasi. Namun gejala awal divertikulitis yaitu, nyeri perut (paling sering di kuadran kiri bawah), mual, muntah, sembelit, demam, dan perut kembung. Selain gejala pemeriksaan fisik juga perlu dilakukan untuk menegakkan diagnosis divertikulitis. Pada pemeriksaan fisik biasanya akan ditemukannya tanda seperti, Nyeri perut lokal, Distensi perut, Perut timpani hingga perkusi, Massa yang lunak (pembentukan abses), Bunyi usus hipo atau hiperaktif, Suara usus yang tidak ada (perforasi), Nyeri perut menyeluruh dengan rebound dan guarding (perforasi), Temuan saluran kemih (fistula colovesicular / colovaginal) termasuk suprapubik, panggul, nyeri tekan costovertebral; pneumaturia (udara dalam urin); fecaluria (feses dalam urin); keputihan purulen. ( Ghoulam, 2019)

Pengobatan divertikulitis dilakukan sesuai dengan tergantung pada seberapa parah kondisi yang dialami. Jika divertikulitis yang dialami berat atau rumit maka diperlukan penanganan reseksi bedah, sedangkan divertikulitis ringan atau tidak rumit dimana belum mengalami komplikasi dapat diberikan pengobatan antibiotik ataupun modifikasi diet. (Strate, 2019). Modifikasi diet contohnya diet tinggi serat untuk mengoptimalkan pergerakan usus mereka, namun ini disarankan setelah episode akut telah diselesaikan. (Tursi, 2013), dan diet FODMAP yang rendah dapat membantu mencegah terulangnya divertikulitis. (uno, 2016)

Beberapa penelitian, menyarankan bahwa diet yang kaya serat makanan menghasilkan pengurangan risiko untuk pengembangan divertikulitis rumit akut. Dalam Studi Tindak Lanjut Profesional Kesehatan (HPFS) yang mencakup 48.000 pria, individu dengan asupan serat tertinggi memiliki pengurangan risiko $42 \%$ untuk pengembangan divertikulitis dibandingkan dengan mereka yang asupan serat terendah ( Bohm, 2015)

\section{PEMBAHASAN}

Divertikulitis merupakan peradangan divertikulum ,adanya infeksi pada divertikulum dan bahkan merupakan suatu komplikasi dari divertikulosis. Sekitar 10\%$25 \%$ komplikasi dari divertikulosis dapat menyebabkan divertikulitis. Patofisiologi dari divertikulitis adalah penyumbatan kantung divertikulum oleh fecalith, yang dengan iritasi pada mukosa menyebabkan peradangan tingkat rendah, kemacetan dan obstruksi lebih lanjut. (Rezapour, 2018)

Divertikulitis memiliki gejala yaitu nyeri perut kuadran kiri bawah, yang biasanya disertai dengan demam dan leukositosis,mual, muntah, perubahan fungsi usus, dan disuria. Gejala lain Peritonitis umum dapat timbul pada kasus parah divertikulitis akut dengan perforasi (Deery,2017). Selain gelaja-gejala tersebut dapat dilakukan pemeriksaan fisik serta pemeriksaan penunjang untuk menegakkan diagnosis. Pemeriksaan fisik yang dapat dilakukan berupa tanda-tanda vital dengan memperhatikan suhu, detak jantung, dan tekanan darah, pemeriksaan abdomen yang cermat untuk menilai lokasi nyeri (biasanya kuadran kiri bawah dan / atau suprapubik), guarding, rebound, dan distensi( Swanson, 2018). Dan pada kasus dapat ditemukan hasil dari pemeriksaan fisik seperti Nyeri perut lokal, Distensi perut, Perut timpani hingga perkusi, Massa yang lunak (pembentukan abses), Bunyi usus hipo atau hiperaktif, Suara usus yang tidak ada (perforasi), Nyeri perut menyeluruh dengan rebound dan guarding (perforasi), Temuan saluran kemih (fistula colovesicular / colovaginal) termasuk suprapubik, panggul, nyeri tekan costovertebral; pneumaturia (udara dalam urin); fecaluria (feses dalam urin); keputihan purulen ( Ghoulam, 2019). Sedangkan pada pemeriksaan penunjang Pasien dengan divertikulitis biasanya datang dengan peningkatan jumlah sel darah putih dan protein C-reaktif (CRP). Peningkatan jumlah sel darah putih dapat meingkat pada kasus divertikulitis tanpa komplikasi walaupun peningkatannya hanya sedikit, namun pada kasus komplikasi peningkatannya jauh lebih tinggi. Pemeriksaan urinalisis dapat disarankan untuk menyingkirkan penyebab nyeri urin dan tes kehamilan pada wanita 
usia subur. Elektrolit dan enzim hati membantu mengesampingkan penyebab nyeri empedu. Pada pasien dengan diare, pemeriksaan feses harus dilakukan untuk menyingkirkan etiologi infeksi ( Swanson, 2018).

Di amerika orang yang berusia lebih dari 60 tahun sekitar $50 \%$ mengalamai divertikulitis. Setiap tahun, di Amerika Serikat (AS), ada lebih dari 2,7 juta kunjungan rawat jalan dan 200.000 rawat inap untuk divertikulitis. Insiden divertikulitis meningkat dari waktu ke waktu. Namun, peningkatan relatif divertikulitis dalam beberapa dekade terakhir telah terbesar pada pasien muda. Sebagai contoh, dari tahun 1980 hingga 2007, kejadian divertikulitis pada individu berusia 40-49 tahun meningkat $132 \%$. Divertikulitis lebih sering terjadi pada pria daripada wanita, namun saat memasuki dekade ke-6 divertikulitis sering terjadi atau lebih umum pada wanita.(Strate, 2019).

Pengobatan divertikulitis dilakukan sesuai dengan tergantung pada seberapa parah kondisi yang dialami. Jika divertikulitis yang dialami berat atau rumit maka diperlukan penanganan reseksi bedah, sedangkan divertikulitis ringan atau tidak rumit dimana belum mengalami komplikasi dapat diberikan pengobatan antibiotik ataupun modifikasi diet. (Strate, 2019). Modifikasi diet contohnya diet tinggi serat untuk mengoptimalkan pergerakan usus mereka, namun ini disarankan setelah episode akut telah diselesaikan. (Tursi, 2013), dan diet FODMAP yang rendah dapat membantu mencegah terulangnya divertikulitis. (uno, 2016)

Diet Divertikulitis dianjurkan pada penderita divertikulitis yang masih dalam tahap yang ringan dan tidak memiliki komplikasi. Tujuan diet divertikulitis yaitu mengistirahatkan usus untuk mencegah perforasi dan mencegah akibat laksatif dari makanan berserat tinggi. Syarat Diet Divertikulitis antara lain, jika terjadi perdarahan maka dimulai dengan makanan cair jernih yang hanya terdiri dari teh, kaldu, air jeruk, air bubur kacang hijau, selanjutnya diberikan cair penuh, seperti makanan cair dengan susu yang terdiri dari susu, maizena, telur ayam, margarin, minyak, gula, sari buah dan diblender menjadi satu, saat keadaan mulai membaik, tekstur makanan dapat ditingkatkan menjadi makanan lunak dengan mengutamakan pemilihan serat larut air dengan jenis sayur yang boleh diberikan adalah daun bayam, labu sian dan wortel. Contoh menu:

Pagi : bubur ayam dengan jus pepaya.

Pukul 10.00 : bubur sum-sum dengan the manis.

Siang : nasi lunak, pepes ikan tenggiri, sup wortel buncis, pisang.

Sore : nasi lunak, tempe bacem, bobor bayam (santan encer), semangka.

Malam : puding susu.

Hidangan ini menggunakan bahan yang mudah dicerna dan teksturnya lunak sehingga tidak memberatkan kerja usus. Jumlah bahan yang digunakan sesuai dengan kaidah gizi seimbang (3-8 porsi $\mathrm{KH}$, 3-4 Protein, 2-3 Sayuran, 3-5 Buah, dan minyak 6-7 porsi). Selanjutnya untuk mencegah terjadinya penyakit ini maka harus mengonsumsi makanan dengan jumlah serat minimal $20 \mathrm{~g}$ setiap hari. Serat $20 \mathrm{~g}$ dapat dicapai dengan konsumsi sayur minimal 2 mangkuk per hari, buah minimal 3 potong, karbohidrat kompleks sesuai kebutuhan dan utamakan memilih yang tinggi serta, yaitu beras merah dan roti gandum. Untuk ccamilan dapat dipilih puding yang terbuat dari agar-agar atau jelly. Kurangi konsumsi gorengan dan konsumsi cairan ditingkatkan minimal 8 gelas setiap hari (Ramayulis, 2016).

Adapun makanan-makanan yang harus dihindari untuk dikonsumsi seperti sereal gandum, makanan pedas, buah-buahan kering dan sayuran. (Wahyuni, 2013).

Sala satu Diet divertikulitis yang dapat dilakukan yaitu diet tinggi serat atau diet rendah FODMAP. Diet tinggi serat biasanya akan dianjurkan setelah episode divertikulitis akut telah diselesaikan, dan disarankan untuk mempertahankan diet tinggi serat untuk mengoptimalkan pergerakan usus mereka. Diet tinggi serat ini masih sangat umum direkomendasikan untuk mengurangi kemungkinan kekambuhan divertikulitis. (Tursi, 2013) Sedangkan untuk diet rendah FODMAP terdapat sebuah teori yang menyatakan bahwa karena peningkatan tekanan dalam usus besar dapat menyebabkan 
perkembangan divertikulum, dan karena diet FODMAP yang rendah dapat membantu mengurangi gas dan kembung, maka diet FODMAP yang rendah dapat membantu mengurangi dan / atau mencegah pembentukan divertikulum. (Gulbin, 2019)

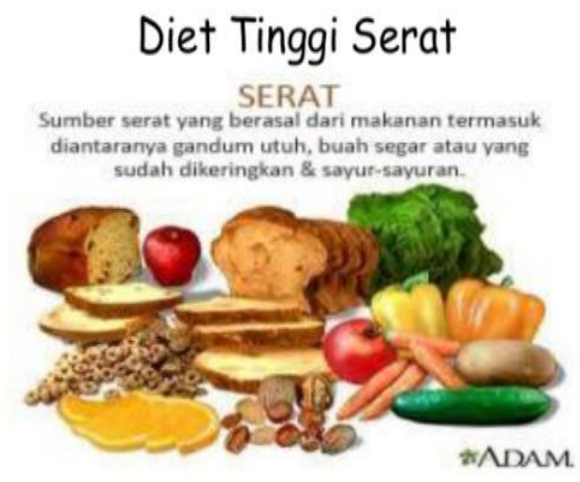

Gambar 3. Diet Tinggi Serat

Diet tinggi serat adalah modifikasi dari susunan makanan biasa dengan menambah bahan pangan yang banyak mengandung serat pangan.

Setelah episode akut divertikulitis telah sembuh, pasien umumnya disarankan untuk mempertahankan diet tinggi serat untuk mengoptimalkan pergerakan usus mereka. Namun, literatur kolektif yang menyelidiki peran modifikasi diet dalam mencegah penyakit divertikular atau kekambuhan divertikulitis tidak konsisten. Bahkan ketika hanya memasukkan studi terbaru, hasilnya bertentangan, dan tidak ada dukungan yang konsisten untuk merekomendasikan diet tinggi serat. Meskipun kurangnya bukti, diet tinggi serat masih umum direkomendasikan. (Tursi, 2012)

Diet tinggi serat seumur hidup bagi mereka dengan penyakit divertikular asimptomatik dapat mengurangi kejadian divertikulitis dan komplikasinya. Panduan American Gastroenterological Association (AGA) 2015 menyarankan diet kaya serat atau suplemen serat pada individu dengan riwayat divertikulitis akut. Namun, pedoman tersebut tidak menyarankan pasien secara rutin untuk menghindari konsumsi popcorn dan kacang-kacangan. (Ghoulam, 2019). Konsumsi diet tinggi serat ini dikaitkan dengan risiko masuk rumah sakit yang lebih rendah dan kematian akibat penyakit divertikular dan berdasarkan pedoman American Gastroenterology Association (AGA) baru-baru ini tentang diverticulitis secara terbuka menyarankan asupan serat makanan yang tinggi pada pasien dengan riwayat divertikulitis akut.(Rezapour, 2018).

Diet rendah FODMAP, FODMAP (Fermentable, Oligosakarida, Disakarida, Monosakarida, serta Poliol), adalah kelompok heterogen dari karbohidrat dan poliol rantai pendek yang sangat mudah difermentasi tetapi kurang terserap. Pedoman British Dietetic Association (BDA) yang baru-baru ini direvisi untuk manajemen diet IBS merekomendasikan diet rendah FODMAP sebagai intervensi lini kedua pada pasien IBS. Meta-analisis 2016 mendukung kemanjuran diet FODMAP rendah dalam pengobatan gejala gastrointestinal fungsional. Pengobatan dengan diet rendah FODMAP juga telah dianjurkan untuk divertikulitis. (Catassi, 2017)

Diet rendah FODMAP digunakan untuk menghindari makanan yang mengandung laktosa. Makanan yang mengandung laktosa tidak hanya menyebabkan peningkatan kadar air di usus (melalui peningkatan beban osmotik di ileum) tetapi juga mudah difermentasi oleh mikrobiota kolon, yang mengarah pada produksi asam lemak rantai pendek dan gas: Terutama hidrogen $(\mathrm{H} 2)$, karbon dioksida (CO2), dan metana ( $\mathrm{CH} 4)$. Sehingga, individu dengan intoleransi laktosa dapat mengalami diare dan distensi perut sebagai akibat dari asupan makanan. (Uno, 2016).

Diet rendah FODMAP direkomendasikan untuk membantu mereka dengan divertikulitis, karena peningkatan tekanan dalam usus besar dapat menyebabkan perkembangan divertikulum, dan karena diet FODMAP yang rendah dapat membantu mengurangi gas dan kembung, maka diet FODMAP yang rendah dapat membantu mengurangi dan / atau mencegah pembentukan divertikulum. (Gulbin, 2019) 


\begin{tabular}{llr}
\multicolumn{1}{c}{ Diet } & rendah & FODMAP \\
menghilangkan & makanan & yang \\
mengandung & Fermentable & foods,
\end{tabular}

Oligosakarida, Disakarida, Monosakarida, dan Poliol. Fermentable foods (Makanan yang dapat difermentasi) seperti yogurt, asinan kubis, dan kombucha. Oligosakarida seperti kacang, kacang polong, lentil, bawang merah, dan bawang putih. Disakarida seperti makanan yang mengandung laktosa seperti susu, krim, es krim, keju cottage, puding, dan produkproduk yang mengandung susu seperti sup, saus, dan saus tertentu. Monosakarida seperti madu dan makanan yang mengandung sirup jagung fruktosa tinggi. Poliol seperti apel, plum, pir, persik, semangka, kembang kol, jamur, kacang polong salju, dan gula alkohol, dapat disebutkan beberapa di antaranya.

Ini adalah contoh rencana makan 4 hari atau menu untuk diet divertikulitis, Tetapi itu tentu juga sesuai untuk rata-rata orang dengan diverticulosis yang ingin meminimalkan risiko terkena diverticulitis. (Leech, 2018).

Pada Hari pertama menu sarapan dapat menggunakan bubur Quinoa dengan Berries dan Kayu Manis. Makan siang dapat berupa Salad tuna dengan bayam, roket, tomat, dan mentimun yang dibumbui dengan minyak zaitun dan cuka sari apel, Makan malam seperti tumis tempe dengan sayuran (wortel / kepala brokoli / sayuran Asia / sayuran bekerja dengan baik dalam kentang goreng). Makanan ringan seperti Wortel dengan keju cottage. Selanjutnya pada Hari kedua menu sarapan dapat menggunakan 2 butir telur (dibuat sesuka hati) di atas $2 \times$ roti putih bebas gluten +1 cangkir bayam / aragula / roket yang dilumuri minyak zaitun dan garam. Makan Siang sisa malam terakhir. Makan malam bisa seperti Ayam panggang atau wajan dengan sayuran panggang FODMAP rendah. Makanan ringan bisa seperti 10 almond / pecan / kenari atau 20 macadamias. Selanjutnya pada Hari Ketiga menu sarapan dapat menggunakan Roti bebas gluten dengan keju cottage dan salmon asap. Makan Siang dapat berupa Tomat Rendah dan FODMAP Leek Frittata. Makan malam dapat berupa Ayam / sapi / ikan (berapapun jumlahnya) +1 sdm kecap / saus $B B Q$ / mustard +2 kentang rebus kecil $+1 / 2$ cangkir brokoli. Makanan ringan dapat berupa 1 jeruk atau 2 buah kiwi kecil. Dan terakhir pada hari keempat pada menu sarapan dapat berupa $1 / 2$ cangkir gandum + 10 raspberry / stroberi / blueberry. Tambahkan air dan microwave untuk membuat bubur hangat, atau cukup tambahkan susu bebas laktosa / susu almond untuk sereal. Makan siang dapat berupa Minestrone FODMAP Rendah. Makan malam dapat berupa Salmon dipanggang dalam oven dengan irisan jeruk nipis dan cabai di atasnya, disajikan dengan 1/2 cangkir zucchini kukus dan labu, dan nasi basmati rebus. Makanan ringan dapat berupa 2 kue beras atasnya dengan selai kacang dan 1/2 pisang.

Ingatlah bahwa Anda mungkin juga ingin mempertimbangkan suplemen vitamin D dan / atau probiotik di samping pola makan sehat.

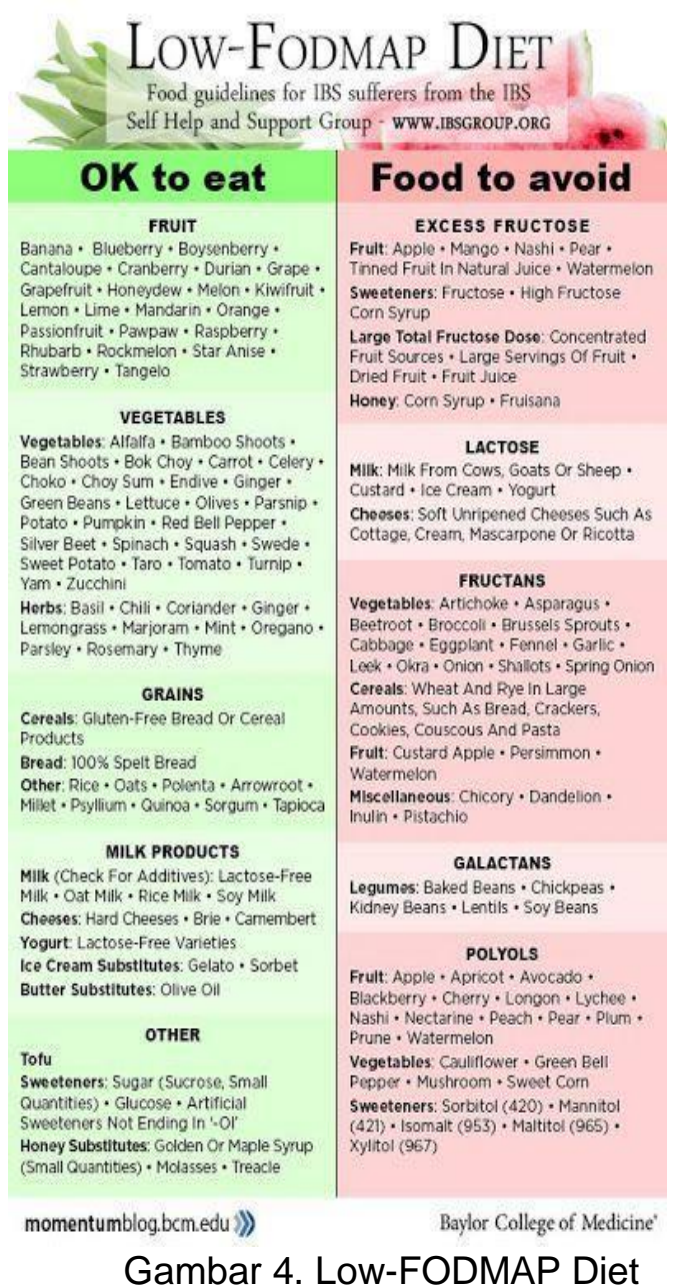

Gambar 4. Low-FODMAP Diet 


\section{KESIMPULAN}

Penyakit divertikular (divertikulosis, divertikulitis) adalah istilah umum untuk keberadaan divertikula, kantung kecil di dinding usus besar (kolon). Patogenesis dari penyakit divertikular bersifat multifaktorial dan diduga berhubungan dengan inflamasi ringan, perubahan mikrobiota kolon, dan disfungsi sistem imun, saraf enterik, dan disfungsi sistem otot. Diverticulitis merupakan suatu diverticulum pecah dan menjadi infeksi atau ketika divertikula meradang atau terinfeksi. Divertikulitis dapat dibedakan menjadi dua yaitu divertikulitis tidak rumit dan divertikultis rumit. Divertikulitis tidak rumit adalah tanpa komplikasi yang melibatkan penebalan dinding kolon dan perubahan inflamasi peri-kolon. Sedangkan, divertikulitis rumit ditandai dengan adanya abses, peritonitis, obstruksi, dan / atau fistula. Diverikulitis ini memiliki gejala seperti mual, muntah, nyeri abdomen, konstipasi, kelemahan dan keletihan. Pengobatan divertikulitis dilakukan sesuai dengan tergantung pada seberapa parah kondisi yang dialami. Jika divertikulitis yang dialami berat atau rumit maka diperlukan penanganan reseksi bedah, sedangkan divertikulitis ringan atau tidak rumit dimana belum mengalami komplikasi dapat diberikan pengobatan antibiotik ataupun modifikasi diet. Diet pada divertukulitis bertujuan mengistirahatkan usus untuk mencegah perforasi dan mencegah akibat laksatif dari makanan berserat tinggi. Diet ini memiliki beberapa syarat dan juga beberapa makanan yang harus dihindari. Diet yang dapat dilakukan seperti diet tinggi serat atau diet rendah FODMAP. Diet tinggi serat adalah modifikasi dari susunan makanan biasa dengan menambah bahan pangan yang banyak mengandung serat pangan. Diet tinggi serat ini memiliki beberapa syarat seperti, energi cukup, protein cukup, lemak cukup, karbohidrat cukup, vitamin dan mineral tinggi, cairan tinggi, dan serat tinggi. Sedangkan, FODMAP (Fermentable, Oligosakarida, Disakarida, Monosakarida, serta Poliol), adalah kelompok heterogen dari karbohidrat dan poliol rantai pendek yang sangat mudah difermentasi tetapi kurang terserap. Diet rendah FODMAP ini menghilangkan makanan yang mengandung Fermentable, Oligosakarida, Disakarida, Monosakarida, serta Poliol.

\section{DAFTAR PUSTAKA}

Böhm, S. K. (2015). Risk factors for diverticulosis, diverticulitis, diverticular perforation, and bleeding: A plea for more subtle history taking. Viszeralmedizin: Gastrointestinal Medicine and Surgery, 31(2), 84-94. https://doi.org/10.1159/000381867

Carabotti, M., \& Annibale, B. (2019). Mesalamine (5-ASA) for the prevention of recurrent diverticulitis (Review). Techniques in Coloproctology, 23(6), 597-599. https://doi.org/10.1007/s10151-01902037-3

Catassi, G., Lionetti, E., Gatti, S., \& Catassi, C. (2017). The low FODMAP diet: Many question marks for a catchy acronym. Nutrients, 9(3). https://doi.org/10.3390/nu9030292

Deery, S. E., \& Hodin, R. A. (2017). Management of Diverticulitis in 2017. Journal of Gastrointestinal Surgery, 21(10), 1732-1741. https://doi.org/10.1007/s11605-0173404-3

Ghoulam, E. M. (2018). Diverticulitis Treatment \& Management. Medscape, 173388. https://emedicine.medscape.com/art icle/173388-treatment\#d3

Gulbin, Staci. (2019). Low FODMAP diet and diverticulitis. Casa de sante.

Leech, Joe. (2018). The Best Diverticulitis Diet: Splitting Fact From Fiction With Over 25 Studies. Diet v.s. disease.

Ramayulis, Rita. (2016). Diet untuk penyakit komplikasi.(I). Jakarta : Penebar plus+ (penebar swadaya grup).

Rezapour, M., Ali, S., \& Stollman, N. (2018). Diverticular disease: An update on pathogenesis and management. Gut and Liver, 12(2), 125-132.

https://doi.org/10.5009/gnl16552

Siegenthaler, Walter. (2007). Differential diagnosis in internal medicine: from symptom to diagnosis. Germany; Thieme Publishing Group 
Strate, L. L., \& Morris, A. M. (2019). Epidemiology, Pathophysiology, and Treatment of Diverticulitis. Gastroenterology, 156(5), 12821298.e1. https://doi.org/10.1053/j.gastro.2018 .12 .033

Swanson, S. M., \& Strate, L. L. (2018). In the Clinic: Acute Colonic Diverticulitis Mini-abstract. HHS Public Access, 168(9), 11. https://doi.org/10.7326/AITC201805 $010 . \ln$

Tursi, A. (2012). Advances in the management of colonic diverticulitis Correspondence to : 184(13), 14701476.

https://doi.org/10.1503/cmaj.120580/ $-/ D C 1$

Tursi, A. (2013). Preventing recurrent acute diverticulitis with pharmacological therapies. Therapeutic Advances in Chronic Disease, 4(6), 277-286. https://doi.org/10.1177/2040622313 498809

Uno, Y., \& Velkinburgh, J. C. van. (2016). Logical hypothesis: Low FODMAP diet to prevent diverticulitis. World Journal of Gastrointestinal Pharmacology and Therapeutics, 7(4), 503. https://doi.org/10.4292/wjgpt.v7.i4.5 03 